\title{
Lead isotopes and archaeometallurgy
}

\author{
F. Cattin • B. Guénette-Beck • M. Besse $\cdot$ V. Serneels
}

Published online: 16 September 2009

(C) Springer-Verlag 2009

This special issue presents several studies applying lead isotope analysis (LIA) to address archaeological questions in the field of ancient mining and metallurgy. They were presented during an international workshop, held in Fribourg (Switzerland), June 19-20, 2008, organised in collaboration between the Geosciences Department of the University of Fribourg and the Laboratory of Prehistoric Archaeology and Human Peopling (Department of Anthropology and Ecology) of the University of Geneva with the financial support of the Swiss National Science Foundation. Dr. F. Cattin and Dr. B. Guénette-Beck were in charge of the scientific organization. More than 30 scientists from Belgium, France, Germany, Italy and Switzerland attended

\section{F. Cattin $(\bowtie) \cdot$ M. Besse}

Département d'anthropologie et d'écologie,

Université de Genève,

12 rue Gustave-Revilliod,

1211 Geneva, Switzerland

e-mail: mail@florencecattin.com

M. Besse

e-mail: marie.besse@unige.ch

B. Guénette-Beck • V. Serneels

Department of Geosciences, University of Fribourg,

Chemin du Musée 6,

1700 Fribourg, Switzerland

B. Guénette-Beck

e-mail: barbara.guenette-beck@unifr.ch

V. Serneels

e-mail: vincent.serneels@unifr.ch

F. Cattin

Département d'anthropologie, Université de Montrèal,

C. P. 6128, succursale Centre-Ville,

Montrèal, QC H3C 3J7, Canada the sessions with the seven key lectures dedicated to different aspects of actual research in the field of LIA.

Over the last few years, several studies of archaeological artefacts using lead isotope analysis have shown a renewed interest in this technique. The workshop aimed to bring together experienced senior researchers and young scientists active in the field to promote contacts and discussions. The idea was to address research questions on four general points:

1. Analytical considerations: possibilities, advantages and shortcomings of various methods like TIMS, ICP-MS and LA-ICP-MS

Since the first application of $\mathrm{Pb}$ isotopic data in archaeology, its acquisition has relied on different analytical methods. From this concern, it is legitimate to ask if one lead isotope analysis is equivalent to another lead isotope analysis. First of all, thermal ionisation mass spectrometry (TIMS) was the only method used in Pb isotope measurement until the introduction of high precision multi-collector inductively coupled plasma mass spectrometer, as detailed in the LIA historical perspective of Stos-Gale and Gale. The more recent development of mass spectrometry with laser ablation reduced the sample size and therefore widened new perspectives of applications, with the opportunity to investigate small or precious artefacts and micro-scale sampling in a heterogeneous matrix. The methodological paper of Villa discusses the protocols of all these techniques, with a focus on the one processed at the Laboratory of Isotope Geology at the University of Berne (Switzerland). What comes out of this contribution is that accuracy should concentrate our full attention when acquiring new data and that precision, whatever high or not, may allow distinction between what needs to be differentiated regarding specific archaeological questions. 
2. LIA in regard with the materials studied, namely what are the specificities of applying LIA to metals such as lead/silver, copper and iron, to natural ores as well as to metallurgy-related traces of $\mathrm{Pb}$ in sediments?

From the beginning, the determination of the provenance of metal artefacts, based on comparison between metallic products and natural ores, has been one of the main questions addressed by LIA and a major expectancy from archaeologists. The technique was first applied to lead and silver ores and metals and then to copper and only very recently to iron. Despite significant success, it became clear that several pitfalls do exist and that LIA interpretation must be made carefully with a good background for the mineral resources, the history of their exploitation and the technology involved.

Regarding the chaîne opératoire of silver, GuénetteBeck et al. highlights the problem of re-melted silver in the case of coin minting. Actually, the control of the silver content in coins requires its purification by cupellation, leading to lead contamination. Lead artefact studies based on lead isotope analysis have also a specificity in the interpretation of the data. As described in Bode et al., when the mixing of two sources of lead is ascertained by a mixing line in binary diagrams, the mixture ratio can be calculated.

Within the chaîne opératoire of copper, the lead isotope composition may be a concern in the case of alloying. Actually, the signature would no longer reflect that of copper, but an intermediate solution of lead issued from the copper and the admixed lead. It is generally considered that lead in tin to produce bronze does not significantly affect the lead signature of the copper.

Moving on to the analytical methods, as described by Degryse et al., LIA of iron artefacts requires a huge amount of sample material (up to several milligrams). This is far more than for lead, silver and copper sampling, with the exception of native copper, for which lead content is generally inferior to $1 \mathrm{ppm}$. The complementary use of $\mathrm{Sr}$ isotopes by Degryse et al., for which TIMS measurements are more precise than $\mathrm{Pb}$ isotopes, is a very interesting way to narrow down the possible sources. In the future, this approach that holds simultaneously elements coming from various elements might be pursued, extended to other isotope systems and applied to different metals. At the same time, the influence of the process on these other elements deserves to be understood.

3. LIA with regard to archaeology, to what kind of archaeological questions can LIA offer new elements for our understanding of the past? How can geoscientists aid in solving archaeological problems and what are the expectations of the archaeologists in this respect?
Archaeology seeks to understand human populations of the past. Nowadays, there is a panel of related disciplines that can be applied to resolve archaeological problems. At present, the use of LIA remains most often restricted to specific fields in the framework of research programs. It has been fieldwork, however, that has been the most productive in terms of archaeological finds and publications. Despite this, we note a scarcity of site monographs that include lead isotope analysis as part of the interpretation of metallic data. Perhaps the lack of knowledge or understanding regarding the potential of the method and the lack of publications in general archaeological journals are to be taken into account. In our opinion, lead isotope analysis should not be restricted to academic research or specific topics as ingots or coins. Indeed, the interpretation of collected data can provide fieldwork archaeology with valuable information. As shown by Cattin et al., this method improves understanding of a settlement and its cultural background within the final Neolithic of western Switzerland. Guénette-Beck et al. relate the exploitation history of $\mathrm{Ag} / \mathrm{Pb}$ ore bodies for the production of silver objects in the metallogenic region of the Valais region, Switzerland, from the Late Iron Age to the Late Mediaeval Period. Degryse et al. contribute new elements related to iron trade routes in Sagalassos (Turkey) from the early Roman period to the early Byzantine period. Bode et al. question the motives of the conquest of Germania by the Roman Empire. They seek to demonstrate Roman-related lead mining east of the Rhine river and then to quantify its economic importance.

4. Methods of establishing databases and their practical use

The paper of Stos-Gale and Gale discusses the databases in LIA. The long developments on methodology and history of data acquisition that it contains highlight the heterogeneity of the data within only the Oxford laboratory. In that sense, the wish to merge into a unique database all available $\mathrm{Pb}$ isotope data for ores and artefacts - and related information on the analytical process, the precision and accuracy, the site coordinates, the geology of the ore body, the mining evidences, the artefacts period of usage, etc.cannot be accomplished without a time-consuming, difficult and multidisciplinary approach. Nevertheless, to give a basis for future research in LIA, a non-exhaustive collection of published papers with lead isotope data for ores and artefacts is presented in the "Appendix". It remains an important concern to make the huge amount of existing data available for all.

Even if this special issue presents only selected LIA approaches, this volume, through the diversity of the papers, already shows a heterogeneous panel in the acquisition and the interpretation of the $\mathrm{Pb}$ isotope data. 
From these approaches, we conclude that a lead isotope analysis cannot be separated from those technical parameters, since they aimed at answering specific questions with the best appropriate tools for it. In the future, hopefully, the development of analytical methods will help improve protocols towards a less and less destructive $\mathrm{Pb}$ isotope acquisition. Simultaneously, analysts, archaeologists and archaeometrists should keep working together on new and complementary ways of research in the quest for material provenances.

As a final remark, we would like to thank the Swiss National Science Foundation for their financial support regarding the organisation of the workshop and for the two doctoral grants that made our research possible.

\section{Appendix}

This appendix presents a non-exhaustive collection of published papers with lead isotope data for $\mathrm{Cu}, \mathrm{Pb} / \mathrm{Ag}$ and $\mathrm{Fe}$ ores, as much as copper, silver, lead and iron artefacts. The scope region is Europe and the Mediterranean World. It has been constructed based on GuénetteBeck (2005) and Cattin (2008) and significantly increased by M. Bode's, P. Degryse's, N. Gale's and S. Stos' suggestions.

Amov B (1999) Lead isotope data for ore deposits from Bulgaria and the possibility for their use in archaeometry. Berlin Beitr Archäom 16:5-19

Arias D, Corretgé LG, Suárez O, Villa L, Cuesta A, Gallastegui G (1996) Lead and sulphur isotope compositions of the Ibias gold vein system (NW Spain): genetic implications. Econ Geol 91:1292-1297

Arribas A, Tosdal RM (1994) Isotopic composition of $\mathrm{Pb}$ in ore deposits of the Betic Cordillera, Spain: origin and relationship to other European deposits. Econ Geol 89:1074-1093

Artioli G, Baumgarten B, Marelli M, Giussani B, Recchia S, Nimis P, Giunti I, Angelini I, Omenetto P (2008) Chemical and isotopic tracers in alpine copper deposits: geochemical links between mines and metal. Geo Alp 5:139-148

Attanasio D, Bultrini G, Ingo M (2001) The possibility of provenancing a series of bronze punic coins found at Tharros (western Sardinia) using the literature lead isotope database. Archaeometry 43(4):529-547

Baker J, Stos S, Waight T (2006) Lead isotope analysis of archaeological metals by multiple-collector inductively coupled plasma mass spectrometry. Archaeometry 48 (1):45-56

Balassone G, Boni M, Di Maio G, Villa IM (2009) Characterisation of metallic artefacts from the Iron Age culture in Campania (Italy): a multi-analytical study. Period Mineral 78(I):45-63
Barnes IL, Shields WR, Murphy TJ, Brill RH (1974) Isotopic analysis of Laurion lead ores. Archaeol Chem 138:1-10

Baron S, Carigna J, Laurent S, Ploquin A (2006) Medieval lead making on Mont-Lozère Massif (Cévennes, France): tracing ore sources using $\mathrm{Pb}$ isotopes. Appl Geochem 21:241-252

Baudo F, Mozzocchin GA, Cairns W (2007) A pilgrim's ampulla from San Giacomo in Paludo (Venice): provenance hypothesis through lead isotope ratio analysis. J Cult Heritage 8:284-288

Beer-Tobey L, Gale NH, Kim H, Stos-Gale ZA (1998) Lead isotope analyses of four late archaic silver ingots from the Selinus hoard. In: Oddy A, Cowell M (eds) Metallurgy in Numismatics 4. Royal Numismatic Society, Special Publication 30. London, pp 385-393

Begemann F, Hauptmann A, Palmieri A, SchmittStrecker S (2002) Chemical composition and lead isotopy of metal objects from the "royal" tomb and other related finds at Arslantepe, Eastern Anatolia. Paléorient 28 (2):43-69

Begemann F, Schmitt-Strecker S (1994) Das Blei von Schiff und Ladung: Seine Isotopie und mögliche Herkunft. In: Hellenkemper-Salies G (ed) Das Wrack. Der antike Schiffsfund von Mahdia, Cologne, pp 1073-1076

Begemann F, Schmitt-Strecker S, Pernicka E, Lo Schiavo F (2001) Chemical composition and lead isotopy of copper and bronze from nuragic Sardinia. Eur J Archaeol 4:43-85

Begemann F, Schmitt-Strecker S (2008) Bleiisotopie und die Provenienz von Metallen. In: Yalçin Ü (ed) Anatolian Metal IV, Der Anschnitt, Beih 21, Deutsches BergbauMuseum Bochum, Bochum, pp 125-134

Bendall Ch (2003) The application of trace element and isotopic analyses to the study of Celtic gold coins and their metal sources. Dissertation, Universität Frankfurt

Bendall C, Wigg-Wolf D, Lahaye Y, Von Kaenel H-M, Brey GP (2009) Detecting changes of Celtic gold sources through the application of trace element and $\mathrm{Pb}$ isotope laser ablation analysis of Celtic gold coins. Archaeometry 51:598-625

Bielicki KH, Tischendorf G (1990) Lead isotope and $\mathrm{Pb}-\mathrm{Pb}$ model age determinations of ores from central Europe and their metallogenetic interpretation. Contrib Mineral Petrol 106:440-461

Bode M (2008) Archäometallurgische Untersuchungen zur Blei-/Silbergewinnung im Germanien der frühen Römischen Kaiserzeit. Dissertation, University of Münster (URN: urn:nbn:de:hbz:6-22579580819. URL: http://nbnresolving.de/urn:nbn:de:hbz:6-22579580819)

Boni M, Di Maio G, Frei R, Villa IM (2000) Lead isotopic evidence for a mixed provenance for Roman water pipes from Pompeii. Archaeometry 42:201-208 
Boni M, Innace A, Köppel V, Früh-Green G, Hansmann W (1992) Late to Post-Hercynian hydrothermal activity and mineralization in southwest Sardinia (Italy). Econ Geol 87:2113-2137

Boni M, Köppel V (1985) Ore-lead isotope pattern from the Iglesiente-Sulcis Area (SW Sardinia) and the problem of remobilization of metals. Miner Deposita 20:185-193

Brauns CM (1995) Isotopenuntersuchungen an Erzen des Siegerlandes. Dissertation, University of Gießen, Germany

Brevart O, Dupré B, Allegre CJ (1982) Metallogenic provinces and the remobilization process studied by lead isotopes: lead-zinc ore deposits from the Southern Massif Central, France. Econ Geol 77:564-575

Brill RH, Wampler JM (1967) Isotope studies of ancient lead. Am J Archaeol 71:63-77

Brockner W (1989) Archäometrische Untersuchungen an Fundmaterial aus Grabungen des Instituts für Denkmalpflege Hannover. Nachr Niedersachs Urgesch 58:185-191

Budd P, Gale D, Pollard AM, Thomas RG, Williams PA (1993) Evaluating lead isotope data: further observations. Archaeometry 35:241-247

Campana N, Maggi R, Stos-Gale ZA, Houghton J (1996) Miniere e metallurgia in Liguria fra IV millenio e IV secolo B. C. In: La miniera, l'uomo e l'ambiente. Convegno di StudiCassino, 2-4 giugno 1994. All'insegna del Giglio. Firenze, pp $15-52$

Canals A, Cardellach E (1997) Ore lead and sulphur isotope pattern from the low-temperature veins of the Catalonian Coastal Ranges (NE Spain). Miner Deposita 32:243-249

Cauet S (1983) Géochimie isotopique du $\mathrm{Pb}$ et du $\mathrm{S}$. Prof Serv Géol Belg 197:1-67

Cattin F (2008) Modalités d'approvisionnement et modalités de consommation du cuivre dans les Alpes au 3e millénaire avant notre ère: apport des analyses métalliques à la connaissance des peuplements du Néolithique final, du Campaniforme et du Bronze ancien. Dissertation, Université de Genève

Chalkias S, Vavelidis M, Schmitt-Strecker S, Begemann F (1988) Geologische Interpretation der Blei-IsotopenVerhältnisse von Erzen der Insel Thasos, der Ägäis und Nordgriechenlands. In: Wagner GA, Weisgerber G (eds) Antike Edel- und Buntmetallgewinnung auf Thasos. Selbstverlag des Deutschen Bergbau-Museums, Bochum, Der Anschnitt Beiheft 6, Veröffentlichungen aus dem Deutschen Bergbau-Museum Bochum 42, pp 59-74

Charef A (1986) La nature et le rôle des phases associées à la mineralization $\mathrm{Pb}-\mathrm{Zn}$ dans les formations carbonatées et leurs conséquences métallogéniques. Etude des inclusions fluides et des isotopes $(\mathrm{H}, \mathrm{C}, \mathrm{O}, \mathrm{S}, \mathrm{Pb})$ des gisements des Malines (France). Dissertation, Université de Nancy, France
Cumming GL, Köppel V, Ferrario A (1987) A lead isotope study of the northeastern Ivrea Zone and the adjoining Ceneri zone (N-Italy): evidence for a contaminated subcontinental mantle. Contrib Mineral Petrol 97:19_ 30

Cumming GL, Richards JR (1975) Ore lead isotope ratios in a continuously changing earth. Earth Planet Sci Lett 28:155-171

Dayton JE, Dayton A (1986) Uses and limitations of lead isotopes in archaeology. In: Olin JS, Blackman MJ (eds) Proceedings of the 24th International Archaeometry Symposium, Washington, pp 13-41

Degryse P, Schneider J, Kellens N, Muchez Ph, Haack U, Loots L, Waelkens M (2007) Tracing the resources of iron working at ancient Sagalassos: a combined lead and strontium isotope study on iron artefacts and ores. Archaeometry 49:75-86

Degryse P, Schneider J, Kellens N, Lauwers V, Waelkens M, Muchez Ph (2009) Radiogenic isotopes in the provenance determination of raw materials: a case of lead and glass recycling at Sagalassos (SW Turkey). J Nord Archaeol Sci 16:15-23

Domergue C, Quarati P, Nesta A, Trincherini PR (2006) Retour sur les lingots de plomb de Comacchio (Ferrara, Italie) en passant par l'archéométrie et l'épigraphie. Phys/ 0605044. Available via arvix. http://arxiv.org/abs/physics/ 0605044. Assessed 5 May 2006

Durali-Müller S (2005) Roman lead and copper mining in Germany: their origin and development through time, deduced from lead and copper isotope provenance studies. Dissertation, Universität Frankfurt am Main

Durali-Müller S, Brey GP, Wigg-Wolf D, Lahaye Y (2007) Roman lead mining in Germany: its origin and development through time deduced from lead isotope provenance studies. J Arch Sci 34:1555-1567

Gale NH (1980) Early Bronze Age lead-silver mining and metallurgy in the Aegean: the ancient workings on Siphnos. In: Craddock PT (ed) Scientific studies in early mining and extractive metallurgy. London, pp 63-80

Gale NH (1989) Archaeometallurgical studies of Late Bronze Age ox-hide copper ingots from the Mediterranean region. In: Hauptmann A, Pernicka E, Wagner GA (eds) Archäometallurgie der Alten Welt. Beiträge zum Internationalen Symposium Old World Archaeometallurgy, Heidelberg 1987. Bochum, pp 247-268

Gale NH (1996) A new method for extracting and purifying lead from difficult matrices for isotopic analysis. Anal Chim Acta 332:15-21

Gale NH (1998) The role of Kea in metal production and trade in the Late Bronze Age. In: Mendoni LG, MazarakisAinian A (eds) Proceedings of the 1994 International Symposium Kea-Kythnos, Historical and Archaeological Researches, Meletemata 27. National Hellenic Research 
Foundation, Athens, \& Diffusion de Boccard, Paris, pp $737-758$

Gale NH (1998) Some aspects and misconceptions of lead isotope analyses of ores and artefacts. In: Merkel J, Barakat K (eds) Proceedings of the First International Conference on Ancient Egyptian Mining and Metallurgy, Cairo, 1995, pp 35-47

Gale NH (1999) Lead isotope characterization of the ore deposits of Cyprus and Sardinia and its application to the discovery of the sources of copper for Late Bronze Age oxhide ingots. In: Young SMM, Pollard AM, Budd P, Ixer RA (eds) Metals in Antiquity, BAR Int Ser 792. Archaeopress, Oxford, pp 110-121

Gale NH (2005) Die Kupferbarren von Uluburun, Teil 2: Bleiisotopen von Bohrkernen aus den Barren. In: Yalcin Ú, Pulak C, Slotta R (eds) Uluburun. Bochum, Deutschen Bergbau-Museum, pp 141-148

Gale NH (2006) Lead isotope studies-Sardinia and the Mediterranean. Provenance studies of artefacts found in Sardinia. Instrumentum 23:29-34

Gale NH (2008) Metal sources for Early Bronze Age Troy and the Aegean. In: Erkanal H, Hauptmann H, Şahoğlu V, Tuncel R (eds) The Aegean in the Neolithic, Chalcolithic and the Early Bronze Age. Ankara University Press, Ankara, pp 203-222

Gale NH, Bachmann HG, Rothenberg B, Stos-Gale ZA, Tylecote RF (1990) The adventitious production of iron in the smelting of copper. In: Rothenberg B, Bachmann HG (eds) Researches in the Arabah 1959-1985. IAMS, University College, London, pp 182-191

Gale NH, Cucuzza N (2004) Il mezzo lingotto Oxhide da Haghia Triada. Creta Antica 5:137-153

Gale NH, Gentner W, Wagner GA (1980) Mineralogical and geographical silver sources of archaic Greek coinage. In: Metcalf DM (ed) Roy Num Soc Special Publication 13, Metallurgy in Numismatics 1. London, pp 3-50

Gale NH, Kayafa M, Stos-Gale ZA (2008) Early Helladic metallurgy at Raphina, Attica, and the role of Lavrion. In: Tzachili I (ed) Aegean Metallurgy in the Bronze Age. Ta Pragmata, Athens, pp. 87-104

Gale NH, Stos-Gale ZA (1981) Cycladic lead and silver metallurgy. Ann Brit Sch Athens 76:169-224

Gale NH, Stos-Gale ZA (1981) Lead and silver in the ancient Aegean. Sci Am 244(6):176-192

Gale NH, Stos-Gale ZA (1982) Bronze Age copper sources in the Mediterranean: a new approach. Science 216:11-19

Gale NH, Stos-Gale ZA, Spitaels P (1982) Perati and Bronze Age silver production in the Laurion, Attica. Miscellanea Graeca 5:97-103

Gale NH, Stos-Gale ZA (1984) Lead isotope and chemical analyses of silver, lead and copper artefacts from Pyla-Kokkinokremos. Appendix V. In: Karageorghis V, Demas M (eds) Pyla-Kokkinokremos. Nicosia, pp 96-103
Gale NH, Stos-Gale ZA (1984) Mystery of Timna's iron solved by lead isotope 'fingerprinting'. IAMS Newsletter 6:6-8

Gale NH, Stos-Gale ZA, Davis JL (1984) The provenance of lead used at Ayia Irini, Keos. Hesperia 53(4):389-406

Gale NH, Stos-Gale ZA, Papastamataki A, Leonis K (1985) Copper sources and copper metallurgy in the Aegean Bronze Age. In: Craddock PT, Hughes MJ (eds) Proceedings of the symposium on Early Furnace Technology, British Museum, London 1982, British Museum Occasional Paper 48, pp 81-102

Gale NH, Stos-Gale ZA, Gilmore GR (1985) Alloy types and copper sources of Anatolian copper alloy artefacts. Anat Studies 35:143-173

Gale NH, Stos-Gale ZA (1986) Oxhide ingots in Crete and Cyprus and the Bronze Age metals trade. Ann Brit Sch Athens 81:81-100

Gale NH, Stos-Gale ZA (1987) Oxhide ingots from Sardinia, Crete and Cyprus and the Bronze Age copper trade. In: Balmuth MS (ed) Studies in Sardinian archaeology III, Nuragic Sardinia and the Mycenaean World. BAR Int Ser 387, pp 135-179

Gale NH, Stos-Gale ZA, Lilov P, Dimirov M, Todorov T (1991) Recent studies of eneolithic copper ores and artefacts in Bulgaria. In: Mohen JP, Eluère C (eds) Découverte du metal. Colloque de l'exposition Le premier or de l'humanité en Bulgarie (Saint-Germain-en-Laye; 1989), Coll. Millénaires 2. Picard, Paris, pp 49-75

Gale NH, Stos-Gale ZA (1996) Lead isotope methodology: the possible fractionation of lead isotope compositions during metallurgical processes. In: Demirci S, Ozer AM, Summers GD (eds) Archaeometry '94, Proceedings of the 29th International Symposium on Archaeometry. TUBITAK, Ankara, pp 287-299

Gale NH, Stos-Gale ZA, Fasnacht W (1997) Movable finds: metal and metalworking. In: Coleman JE, Barlow JA, Mogelonsky MK, Schaar KW (eds) Alambra, a Middle Bronze Age site in Cyprus. Investigations by Cornell University 1974-1985, pp 129-141, 371-438

Gale NH, Stos-Gale ZA, Maliotis G, Annetts N (1997) Lead isotope data from the Isotrace Laboratory, Oxford: archaeometry data base 4, ores from Cyprus. Archaeometry 39(1):237-246

Gale NH, Stos-Gale ZA (1999) Copper oxhide ingots and the Aegean metals trade: new perspectives. In: Betancourt P, Karageorghis V, Laffineur R, Niemeyer WD (eds) Festschrift for Malcolm Wiener, Meletemata, Aegaeum 20:267-278

Gale NH, Stos-Gale ZA, Radouncheva A, Ivanov I, Lilov P, Todorov T, Panayotov I (2000) Early metallurgy in Bulgaria. In: Annuary of department archaeology, volume 4-5. New Bulgarian University, Institute of Archaeology 
with Museum, Bulgarian Academy of Sciences, Sofia, pp 102-168

Gale NH, Stos-Gale ZA (2000) Lead isotope analyses applied to provenance studies. In: Ciliberto E, Spoto G (eds) Modern analytical methods in art and archaeology. Wiley, New York, pp 503-584

Gale NH, Stos-Gale ZA (2002) Archaeometallurgical research in the Aegean. In: Bartelheim M, Pernicka E, Krause R (eds) Die Anfänge der Metallurgie in der Alten Welt. Verlag Marie Leidorf, Rahden, pp 277-302

Gale NH, Stos-Gale ZA (2005) Zur Herkunft der Kupferbarren aus dem Schiffswrack von Uluburun und der spätbronzezeitliche Metallhandel im Mittelmeerraum. In: Yalcin U, Pulak C, Slota R (eds) Das Schiff von Uluburun-Welthandel vor 3000 Jahren. Bochum, pp 117132

Gale NH, Stos-Gale ZA (2008) Changing patterns in Prehistoric Cycladic metallurgy. In: Brodie N, Doole J, Gavalas G, Renfrew C (eds) Horizon. McDonald Institute for Archaeological Research, Cambridge, pp 387-408

Gardiner V (2001) An analysis of Romano-British lead pigs. IAMS 21:11-13

Gebel A, Schmidt KH (2000) Analyse der Pb-Isotopie römischer Silbermünzen mit Hilfe der Laserablation-ICP-MS. In: Hollstein W (ed) Metallanalytische Untersuchungen an Münzen der Römischen Republik, Berliner Numismatische Forschungen, vol. 6, Gebr. Mann Verlag, Berlin, pp 55-70

Gottschalk R, Baumann A (2001) Material provenance of late Roman lead coffins in the Rheinland, Germany. Eur J Mineral 13:197-205

Graeser S, Friedrich G (1970) Zur Frage der Altersstellung und Genese der Blei-Zink-Vorkommen der Sierra de Cartagena in Spanien. Miner Deposita 5:365-374

Grögler N, Geiss J, Grünenfelder M, Houtermans FG (1966) Isotopenuntersuchungen zur Bestimmung der Herkunft römischer Bleirohre und Bleibarren. Zeitschr Naturforsch 21:1167-1172

Guénette-Beck B (2005) Minerais, métaux, isotopes: recherches archéométriques sur les mines de plomb et d'argent en Valais, Suisse. Dissertation, Université de Lausanne

Gulson BL (1986) Lead isotopes in mineral exploration. Developments in economic geology 23, Elsevier, Amsterdam

Haak U, Lévêque L (1995) Bleiisotope: Anwendung in Lagerstättenkunde, Archäometrie und Umweltforschung am Beispiel des Harzes. Mitt Österr Miner Ges 140:131141

Halberg A (1989) Metal sources in the Early Proterozoic Svecofennian terrain of central Sweden: $\mathrm{Pb}$ isotope evidence. Miner Deposita 24:250-257

Hardwick N, Stos-Gale ZA, Cowell M (1998) Lead isotope analyses of Greek coins of Chios from the 6th -4 th centuries B.C. In: Oddy A, Cowell M (eds) Metallurgy in
Numismatics 4. Royal Numismatic Society, Special Publication 30. London, pp 367-384

Hauptmann A, Begemann F, Heitkemper E, Pernicka E, Schmitt-Strecker S (1992) Early copper produced at Feinan, Wadi Araba, Jordan: the composition of ores and copper. Archaeomaterials 6:1-33

Hildebrandt LH (1998) Die Schwermetallbelastungen durch den historischen Bergbau im Raum Wiesloch. Dissertation, University of Heidelberg, Germany

Hirao Y, Enomoto J, Tachikawa H (1995) Lead isotope ratios of copper, zinc and lead minerals in Turkey in relation to the provenance study of artefacts. In: Prince Takahito Mikasa HIH (ed) Essays on Ancient Anatolia and its surrounding civilisations. Harrassovitz Verlag, Wiesbaden, pp 89-114

Höhndorf A, Large D, Schaeffer R (1984) Blei-Isotopen in Bildungen der postvaristischen Mineralisationen in Norddeutschland. In: Gesellschaft Deutscher Metallhüttenund Bergleute (eds) Posvaristische Gangmineralisationen in Mitteleuropa. Alter, Genese und wirtschaftliche Bedeutung, Weinheim, pp 271-281

Höppner B, Bartelheim M, Huijsmans M, Krauss R, Martinek K, Pernicka E, Schwab R (2005) Prehistoric copper production in the Inn Valley (Austria), and the earliest copper in central Europe. Archaeometry 47(2):293315

Horner J, Neubauer F, Paar WH, Hansmann W, Koeppel V, Robl K (1997) Structure, mineralogy, and $\mathrm{Pb}$ isotopic composition of the As-Au-Ag deposit Rotgülden, Eastern Alps (Austria): significance for formation of epigenetic ore deposits within metamorphic domes. Miner Deposita 32:555-568

Hunt Ortiz, MA (2001) El depósito de la Ría de Huelva: Datos isotópicos para la determinación de su procedencia. In: Gómez Tubío BM, Respaldiza MA, Rodríguez LP (eds) III Congreso National de Arqueometría, Sevilla, pp 487-496

Hunt Ortiz M (2003) Prehistoric mining and metallurgy in south west Iberian Peninsula. Archaeopress, Oxford, BAR Int ser 1188

Joel EC, Taylor T, Ixer RA, Goodway M (1997) Lead isotope analysis and the Great Orme mine. In: Sinclair A, Slater E, Gowlett J (eds) Archaeological sciences 1995, Oxford. Proceedings of a conference on the application of scientific techniques to the study of archaeology (Liverpool; July 1995), Oxbow monograph 64, pp 129-137

Karageorghis V, Gale NH, Stos-Gale ZA (1983) Two silver ingots from Cyprus. Antiquity 57:211-214

Kayafa M, Stos-Gale ZA, Gale NH (2000) The circulation of copper in the Early Bronze Age in Mainland Greece: the lead isotope evidence from Lerna, Lithares and Tsoungiza. In: Pare C (ed) Metals make the world go round: supply and circulation of metals in Bronze Age Europe. Oxbow Books, Oxford, pp 39-55 
Kinnaird JA, Ixer RA, Barreiro B, Nex PAM (2002) Contrasting sources for lead in Cu-polymetallic and $\mathrm{Zn}-\mathrm{Pb}$ mineralisation in Ireland: constraints from lead isotopes. Miner Deposita 37:495-511

Klein S, Lahaye Y, Brey G, von Kaenel HM (2004) The early Roman Imperial aes coinage II: tracing the copper sources by analysis of lead and copper isotopes-copper coins of Augustus and Tiberius. Archaeometry 46(3):469-480

Klein S, Rico C, Lahaye Y, von Kaenel HM, Domergue C, Brey GP (2007) Copper ingots form the western Mediterranean Sea: chemical characterisation and provenance studies through lead- and copper isotope analyses. J Roman Archaeol 20(1):202-221

Köppel V (1983) Summary of lead isotope data from ore deposits of the Eastern and Southern Alps: some metallogenetic and geotectonic implications. In: Schneider HJ (ed) Mineral deposits of the Alps and of the Alpine epoch in Europe. Springer, Berlin, Heidelberg, pp 163-168

Köppel V (1984) Lead isotopes as tracers of the origin of metals in ore deposits and the evolution of continental crust: examples from western and central Europe. Proceedings 27th International Geol Congr Metallogenesis and Mineral Ore Deposits 12, pp 53-82

Köppel V (1997) Bleiisotope. In: Weber L (ed) Handbuch der Lagerstätten der Erze, Industrieminerale und Energierohstoffe Österreichs-Erläuterungen zur Metallogenetischen Karte von Österreich 1:500.000 unter Einbeziehung der Industrieminerale und Energierohstoffe. Arch Lagerst forsch Geol B-A 19, pp 485-495

Köppel V, Schroll E (1983) Lead isotopes of Palaeozoic, strata-bound to stratiform galena bearing sulfide deposits of the Eastern Alps (Austria): implications for their geotectonic setting. Schweiz Mineral Petrogr Mitt 63:347-360

Köppel V, Schroll E (1983) Bleiisotope und Remobilisation von Erzlagerstätten. Erdwiss Komm 6:39-51

Kouzmanov K (2001) Genèse des concentrations en métaux de base et précieux de Radka et Elshitsa (zone de Sredna Gora, Bulgarie): une approche par l'étude minéralogique, isotopique et des inclusions fluides. Dissertation, Université d'Orléans

Krahn L, Baumann A, Friedrich G (1987) Zur Herkunft der Metalle in Vererzungen des Linksrheinischen Schiefergebirges und angrenzender Gebiete: Ergebnisse von BleiIsotopen-Analysen. Fortschr Miner 65:1-106

Krahn L, Baumann A (1996) Lead isotope systematics of epigenetic lead-zinc mineralization in the western part of the Rheinisches Schiefergebirge, Germany. Miner Deposita 31:225-237

Kuleff I, Djingova R, Alexandrova A, Vakova V, Amov B (1995) INAA, AAS, and lead isotope analysis of ancient lead anchors from the Black Sea. J Radioanal Nucl Chem 196:65-76
Kuleff I, Iliev I, Pernicka E, Gergova D (2006) Chemical and lead isotope compositions of lead artefacts from ancient Thracia (Bulgaria). J Cult Heritage 7:244-256

Kunstmann L (2003) Archäologische und archäometallurgische Untersuchungen zum Röstprozess in der spätbronzezeitlichen Kupfermetallurgie in den Ostalpen. Dissertation, Universität Freiberg

Large D, Schaeffer R, Höhndorf A (1983) Lead isotope data from selected galena occurrences in the North Eifel and North Sauerland, Germany. Miner Deposita 18:235243

Lattanzi P, Hansmann W, Köppel V, Costagliola P (1992) Source of metals in metamorphic ore-forming processes in the Apuane Alps (NW Tuscany, Italy): constraints by $\mathrm{Pb}$-isotope data. Mineral Petrol 45:217-229

Lévêque L, Jakobus R (1994) Bleiisotope in Galeniten der postvariszischen Quarz- und Mineralgänge des Osttaunus. Geol Jb Hessen 122:75-80

Le Guen M, Orgeval JJ, Lancelot J (1991) Lead isotope behaviour in a polyphased $\mathrm{Pb}-\mathrm{Zn}$ ore deposit: Les Malines (Cévennes, France). Miner Deposita 26:180-188

Lescuyer JL, Leistel JM, Marcoux E, Milési JP, Thiéblemont D (1998) Late Devonian-Early Carboniferous peak sulphide mineralization in the Western Hercynides. Miner Deposita 33:208-220

Lillo J (1992) Vein-type base-metal ores in Linares-La Carolina (Spain): ore-lead isotopic constrains. Eur J Miner 4:337-343

Lippolt HJ, Schorn U, Pidgeon RT (1983) Genetic implications of new lead isotope measurements on Schwarzwald and Upper Triassic sediment galenas. Geol Rundsch 72:77-104

Ludwig KR, Vollmer R, Turi B, Simmons KR, Perna G (1989) Isotopic constrains on the genesis of basement ores in southern and central Sardinia. Eur J Miner 1(5):657-666

McGeehan Liritzis V, Gale N (1988) Chemical and lead isotope analyses of Greek Late Neolithic and Early Bronze Age metals. Archaeometry 30(2):199-225

Marcoux E (1986) Isotopes du plomb et paragenèses métalliques, traceurs de l'histoire des gîtes minéraux. Illustration des concepts de sources, d'héritage et de régionalisme dans les gîtes français, application en recherche minière. Clermont-Ferrand (Thèse d'état), Document du BRGM 117

Marcoux E (1998) Lead isotope systematics of the giant massive sulphide deposits in the Iberian Pyrite belt. Miner Deposita 33:45-58

Marcoux E, Moëlo Y, Picot P, Baubron JC (1988) Evolution minéralogique et isotopique $(\mathrm{Pb})$ du filon sulfuré complexe des Borderies (Massif central français): implications métallogéniques. Miner Deposita 23:58-70

Niederschlag E, Pernicka E, Seifert T, Bartelheim M (2003) The determination of lead isotope ratios by multiple 
collector ICP-MS: a case study of early Bronze age artefacts and their possible relation with ore deposits of the Erzgebirge. Archaeometry 45:61-100

Nielsen S, Andersen JH, Baker JA, Christiensen C, Glastrup J, Grootes PM, Huls M, Jouttijarvi A, Larsen EB, Madsen HB, Muller K, Nadeau MJ, Rohrs S, Stege H, Stos ZA, Waight TE (2005) The Gundestrup Cauldron-new scientific and technical investigations. Acta Archaeol 76:29-39, 54-55

Northover JPN, O'Brien W, Stos S (2001) Lead isotope and metal circulation in Beaker/Early Bronze Age Ireland. J Irish Archaeol 10:25-47

Pasteels P, Netels V, Dejonghe L, Deutsch S (1980) La composition isotopique du plomb des gisements belges. Implication sur les plans génétique et économique. Bull Soc Belg Géol 89:123-136

Pernicka E (1987) Erzlagerstätten in der Ägäis und ihre Ausbeutung im Altertum: Geochemische Untersuchungen zur Herkunftsbestimmung archäologischer Metallobjekte. Jahrb Römisch-Germanisch Zentralmuseums Mainz 34:607-714

Pernicka E (1992) Evaluating lead isotope data: comments on Sayre et al. 'Statistical evaluation of the presently accumulated lead isotope data from Anatolia and surrounding regions' Comments III. Archaeometry 34:322-326

Pernicka E (1993) Comments on Budd et al. 'Evaluating lead isotope data: further observations' Comments III. Archaeometry 35:259-262

Pernicka E, Begemann F, Schmitt-Strecker S (1993) Eneolithic and early Bronze age copper artefacts from the Balkans and their relation to Serbian copper ores. Praehist Z 68:1-55

Pernicka E, Eibner C, Oztunali Ó, Wagner GA (2003) Early Bronze Age metallurgy in the northeast Aegean. In: Wagner GA, Pernicka E, Uerpmann HP (eds) Ancient Troia and the Troad: scientific approaches. Springer Verlag, Berlin, Heidelberg, New York, pp 143-172

Piccotini G, Schroll E, Spindler P (2003) Ein römerzeitlicher Bleibarren von Magdalensberg. In: Rudolfinum. Jahrbuch des Landesmuseums Kärnten 2002/2003, Klagenfurt, pp 153-161

Pinarelli L (2004) Lead isotope characterisation of copper ingots from Sardinia (Italy): inferences on their origins. Bull Geol Soc Greece 36:1173-1180

Pinarelli L, Salvi D, Ferrera G (1995) The source of ancient Roman lead, as deduced from lead isotopes: the ingots from the Mal di Ventre wreck (western Sardinia, Italy). Sci Technol Cult Herit 4:79-86

Pomies C, Cocherie A, Guerrot C, Marcoux E, Lancelot $\mathrm{J}$ (1998) Assessment of the precision and accuracy of leadisotope ratios measured by TIMS for geochemical applications: example of massive sulphide deposits (Rio Tinto, Spain). Chem Geol 144(1-2):137-149
Ponting M, Evans JA, Pashley V (2003) Fingerprinting of roman mints using laser-ablation MC-ICP-MS lead isotope analysis. Archaeometry 45:591-597

Prange M, Ambert P (2005) Caractérisation géochimique et isotopique des minerais et des métaux base cuivre de Cabrières (Hérault). In: Ambert $\mathrm{P}$, Vaquer $\mathrm{J}$ (eds) La première métallurgie en France et dans les pays limitrophes, [Paris], Soc préhist fr, Actes du colloque international (Carcassonne ; 28-30 Septembre 2002), Soc préhist fr, mémoire 37, pp 71-81

Rodá I (2004) Agripa y el comercio del plomo. Rev Mus Arqueol Munic Cartag 3:183-194

Rohl B (1996) Lead isotope data from the Isotrace Laboratory, Oxford: archaeometry data base 2, galena from Britain and Ireland. Archaeometry 38(1):165-180

Rohl B, Needham S (1998) The circulation of metal in the British Bronze Age: the application of lead isotope analysis. British Museum, London, British Museum Occasional Paper 102

Ruiz C, Arribas A, Arribas Jr A (2002) Mineralogy and geochemistry of the Masa Valverde blind massive sulphide deposit, Iberian Pyrite Belt (Spain). Ore Geol Rev 19:1-22

Rychner V, Stos-Gale S (1998) Compositions chimiques et isotopiques du plomb: la production métallique de l'Âge $\mathrm{du}$ Bronze moyen et final en Suisse. In: Mordant Cl, Pernot M, Rychner V (eds) L'Atelier du bronzier en Europe du $\mathrm{XXe}$ au VIIIe siècle avant notre ère : les analyses de composition du metal : leur apport à l'archéologie de l'Âge du Bronze, vol I. Colloque int. Bronze (Neuchâtel et Dijon : session de Neuchâtel ; 1996), Eds du CTHS, Paris, pp 153 174

Santos Zalduegui JF, García de Madinabeitia S, Gil Ibarguchi JI, Palero F (2004) A lead isotope database: the Los Pedroches-Alcudia area (Spain): implications for archaeometallurgical connections across southwestern and southeastern Iberia. Archaeometry 46(4):625-634

Sayre EV, Yener KA, Joel EC, Barnes IL (1992) Statistical evaluation of the presently accumulated lead isotope data from Anatolia and surrounding regions. Archaeometry 34:73-105

Sayre EV, Joel EC, Blackman MJ, Yener KA, Özbal H (2001) Stable lead isotope studies of Black Sea Anatolian ore sources and related Bronze age and Phrygian artefacts from nearby archaeological sites. Appendix: new Central Taurus ore data. Archaeometry 43(1):77-115

Scaife B, Barreiro BA, McDonell JG, Pollard AM (2001) Lead isotope ratios of 36 galenas from the Northern Pennines, http://brettscaife.net/lead/npennine/npennine. html, latest version: 7/22/2008

Schaeffer R (1984) Die postvariszischen Mineralisationen im nordöstlichen Rheinischen Schiefergebirge. Braunschweiger geologisch-paläontologische Dissertationen 3:1206 
Schaeffer R (1986) Geochemische Charakteristik und Genese der jungmesozoisch-tertiären Vererzungen im Sauerland (Rheinisches Schiefergebirge). Fortschr Geol Rheinl Westfal 34:337-381

Schmitt-Strecker S, Begemann F (2005) Kupfer- und bronzezeitliche Metallartefakte vom Westbalkan: Zur Frage nach den Quellen ihres Kupfers. Praehist Z 80:49-64

Schneider J (1998) Die Herkunft des Siegerländer Münzsilbers. Denkmalpfl Forsch Westf 34:202-221

Schwab R, Heger D, Höppner B, Pernicka E (2006) The provenance of iron artefacts form Manching: a multitechnique approach. Archaeometry 48(3):433-452

Schwab R, Höppner B, Pernicka E (2003) Studies in technology and provenance of iron artefacts from the Celtic Oppidum of Manching (Bavaria). Proc of the International Conference on Archaeometallurgy in Europe (24-26 Sept 2003, Milan, Italy), pp 545-554

Seeliger TC, Pernicka E, Wagner GA, Begemann F, Schmitt-Strecker SF, Eibner C, Öztunali Ö, Baranyi I (1985) Archaeometallurgische Untersuchungen in Nordund Ostanatolien. Jahrb Römisch-Germanisch Zentralmuseums Mainz 32:597-659

Segal I, Halicz L (2005) Provenance studies in archaeometallurgy using lead isotope ratio determination by Q-ICP-MS and MC-ICP-MS. Israel J Earth Sci 54:87-96

Sinclair AJ, Macquar JC, Rouvier H (1993) Reevaluation of the lead isotopic data, southern Massif Central, France. Miner Deposita 28:122-128

Slobodník M, Jacher-Sliwczynska K, Taylor MC, Schneider J, Dolnícek Z (2008) Plumbotectonic aspects of polymetallic vein mineralization in Paleozoic sediments and Proterozoic basement of Moravia (Czech Republic). Int J Earth Sci (Geol Rundsch) 97:1-18

Soles J, Stos-Gale ZA (2004) The metal finds and their geological sources. In: Soles JS, Davaras C (eds) Mochlos IC, Period III. Neopalatial settlement on the coast: the Artisans Quarter and the Farmhouse at Chalinomouri. The small finds. INSTAP Academic Press, Philadelphia, PA, pp 45-60

Stos ZA (2009) Across the wine dark seas ... sailor tinkers and royal cargoes in the Late Bronze Age eastern Mediterranean. In: Shortland AJ, Freestone IC, Rehren T (eds) From mine to microscope - advances in the study of ancient technology. Oxbow Books, Oxford

Stos ZA, Gale NH, Houghton J, Speakman R (1995) Lead isotope data from the Isotrace Laboratory, Oxford: archaeometry data base 1, ores from the western Mediterranean. Archaeometry 37(2):407-415

Stos ZA, Gale NH, Annetts N (1996) Lead isotope data from the Isotrace Laboratory, Oxford: archaeometry data base 3, ores from the Aegean, Part I. Archaeometry 38 (2):381-390
Stos Z, Gale N (2006) Lead isotope and chemical analyses of slags from Chrysokamino. In: Betancourt PP (ed) The Chrysokamino metallurgy workshop and its territory. Hesperia, Supplement 36. The American School of Classical Studies at Athens, pp 298-319

Stos-Gale ZA (1989) Cycladic copper metallurgy. In: Hauptmann A, Pernicka E, Wagner GA (eds) Archäometallurgie der Alten Welt: Beiträge zum Internationalen Symposium "Old World archaeometallurgy", Heidelberg $1987=$ Old World archaeometallurgy: proceedings of the International Symposium "Old World archaeometallurgy", Heidelberg 1987. Selbstverl. des Deutschen BergbauMuseums, Bochum, Der Anschnitt, Beiheft 7, Veröffentlichungen aus dem Deutschen Bergbau-Museum Bochum 44, pp 279-291

Stos-Gale ZA (1992) L'analisi dei rapporti isotopici del piombo. In: Nicosia F, Diana M (eds) La Chimera D'Arezzo. Il Torchio. Florence, pp 128-131

Stos-Gale ZA (1992) The origin of metal objects from the Early Bronze Age site of Thermi on Lesbos. Oxford J Archaeol 11(2):155-178

Stos-Gale ZA (1993) Isotopic analyses of ores, slags and artefacts: the contribution to archaeometallurgy. In: Francovich $\mathrm{R}$ (ed) Archeologia delle attivita estrattive e metallurgiche (proceedings of a Summer School in Certosa di Pontignano-Campiglia Marittima September 1991). Quaderni del Dipartimento di Archeologia e Storia delle Arti, Sezione Archeologica-Universita di Siena. Edizioni All'insegna de Giglio S.A.S. Florence, pp 593-627

Stos-Gale ZA (1993) Lead isotope provenance studies of the early Minoan weapons. In: Scarre C, Healy F (eds) Trade and exchange in Prehistoric Europe. Oxbow Books, Oxford, pp 115-129

Stos-Gale ZA (1993) The origin of copper based metals from the Roman period settlement of Jakuszowice in Southern Poland. J Eur Archaeol 1(2):101-131

Stos-Gale ZA (1998) The role of Kythnos and other Cycladic islands in the origins of Early Minoan metallurgy. In: Mendoni L, Mazarakis A (eds) Meletimata 27, Kea-Kythnos: history and archaeology: Proceeding of the Kea-Kythnos Conference, Kea June 1994. Diffusion de Broccard, Paris, Athens, pp 717-736

Stos-Gale S (1999) Informe sobre los analysis de artefactos metalicos de la Cova des Carritx, Es Forat de Ses Aritges y la Cova des Mussol. In: Lull V, Mico R, Rihuete Herrada C, Risch R (eds) Ideologia y sociedad en la prehistoria Menorca. La Cova des Carritx y la Cova des Mussol. Consell Insular de Menorca, IMGESA Barcelona, pp 643-650

Stos-Gale ZA (2001) The impact of the natural sciences on studies of Hacksilber and early silver coinage. In: Balmuth $\mathrm{M}$ (ed) Hacksilber to coinage: new insights into the monetary history of the Near East and Greece. Numis- 
matic Studies 24. The American Numismatic Society, New York, pp 53-76

Stos-Gale ZA (2001) The development of Spanish metallurgy and copper circulation in Prehistoric Southern Spain. In: Gomez Tubio BM, Respaldiza MA, Pardo Rodriguez ML (eds) III Congreso Nacional de Arqueometria. Secretariado de Publicaciones Universidad de Sevilla, Sevilla, pp 445-456

Stos-Gale S (2004) Lead isotope analyses of glass, glazes and some metal artifacts. In: Bass GF, Matthews SD, Steffy JR, van Doorninck FH (eds) Serce Limani, an eleventh-century shipwreck, Vol I, Texas University Press, College Station, INA series, pp 453-470

Stos-Gale ZA (2006) Provenance of metals from Tell Jatt based on their lead isotope analyses. In: Artzy M, The Jatt metal Hoard in Northern Canaanite/Phoenician and Cypriot context. Cuadernos de Arquelogia Mediterranea 14. Publicaciones del Laboratorio de Arqueologia Universidad Pompeu Fabra de Barcelona, pp 115120

Stos-Gale ZA, Gale NH (1982) Sources of Mycenaean silver and lead. J Field Archaeol 9:467-485

Stos-Gale ZA, Gale NH, Gilmore GR (1984) Early bronze age Trojan metal sources and Anatolians in the Cyclades. Oxford J Archaeol 3(3):23-43

Stos-Gale ZA, Gale NH (1990) The role of Thera in the Bronze Age metal trade. In: Hardy A (ed) Proceedings of the III Thera Congress, Thera and the Aegean World III. Thera Foundation, London. Vol I, pp 72-92

Stos-Gale ZA, Gale NH (1992) Sources of copper used on Thasos in Late Bronze and Early Iron Age. In: Koukouli-Chrysantaki Ch (ed) Proto-historic Thasos. (Protoistoriki Tasos.) Vol. B. Tameio Arhaiologikon Poron kai Apallotrioseon. Athens, pp 781-793

Stos-Gale ZA, Gale NH (1992) New light on the provenience of the copper oxhide ingots found on Sardinia. In: Tykot RH, Andrews TK (eds) Sardinia in the Mediterranean: a footprint in the sea: studies in Sardinian archaeology presented to Miriam S. Balmuth. Sheffield Academic Press, Sheffield, Monographs in Mediterranean archaeology 3, 317-346

Stos-Gale ZA, Gale NH (1994) The origin of metals excavated on Cyprus. Chapter 3. In: Knapp B, Cherry J (eds) Provenance studies and Bronze Age Cyprus: production exchange and politico-economic change. Prehistory Press, Madison, pp 92-122, 210-216

Stos-Gale ZA, Gale NH, Houghton J (1995) The origin of copper metal excavated in El Amarna. In: Davies WV, Schofield L (eds) Egypt, the Aegean and the Levant: interconnections in the 2nd millennium BC. British Museum Press, London, pp 127-135

Stos-Gale ZA, Gale NH, Annetts N, Todorov T, Lilov P, Raduncheva A, Panayotov I (1998) Lead isotope data from the Isotrace laboratory, Oxford: archaeometry data base 5, ores from Bulgaria. Archaeometry 40:217-226

Stos-Gale ZA, Gale NH, Bass G, Pulak C, Galili E, Sharvit J (1998) The copper and tin ingots of the Late Bronze Age Mediterranean: new scientific evidence. In: Proceedings of the Fourth International Conference on the Beginning of the Use on Metals and Alloys (BUMAIV). The Japan Institute of Metals, Aoba, Japan, pp 115126

Stos-Gale ZA, Gale NH, Evely D (2000) An interpretation of the metal finds using lead isotope and chemical analytical procedures. In: Hallager E, Hallager BP (eds) The Greek Swedish Excavations at the Agia Aikaterini Square Kastelli, Khania 1970-1987. Vol. II. Paul Åströms Förlag, Stockholm, pp 206-214

Stos-Gale ZA, Gale NH (2003) Lead isotopic and other isotopic research in the Aegean. In: Foster K, Laffineur R (eds) METRON, Proceedings of the 9th International Aegean Conference (Yale 2002), pp 83-101

Stos-Gale ZA, Hunt-Ortiz M, Gale NH (1999) Report on the results of the elemental and lead isotope analyses of metal artefacts from Gatas and other archaeological sites in its region, and of copper and lead ores from south-east Spain. In: Castro P, Chapman RW, Gili S, Lull V, Miro R, Rimete C, Rische R, Sanahuja ME (eds) Proyecto Gatas 2. La dinamica arqueoecológica de la ocupación prehistórica. Arqueologia Monografias. Junta de Andalucía, Sevilla, pp 311-319

Stos-Gale ZA, Kayafa M, Gale NH (1999) The origin of metals from the Bronze Age site of Nichoria. Opuscula Atheniensia 24:99-120

Stos-Gale ZA, Maliotis G, Gale NH, Annetts N (1997) Lead isotope characteristics of the Cyprus copper ore deposits applied to provenance studies of copper oxhide ingots. Archaeometry 39(1):83-123

Stos-Gale ZA, Maliotis G, Gale N (1998) A preliminary survey of the Cypriot slag heaps and their contribution to the reconstruction of copper production on Cyprus. Der Anschnitt, Beiheft 8:235-262

Stos-Gale ZA, Sampson A, Mangou E (1999) Analyses of metal artefacts from the Early Helladic cemetery of Manika on Euboea. Aegean Archaeology 3, 1996. Art and Archaeology, Warsaw, pp 49-62

Swainbank IG (1982) Lead isotopic composition of some galena ores from Sardinia. Period Miner 51:275-286

Tornos F, Chiaradia M (2004) Plumbotectonic evolution of the Ossa Morena zone, Iberian Peninsula: tracing the influence of mantle-crust interaction in ore-forming processes. Econ Geol 99:965-985

Tornos F, Ribera F, Shepard TJ, Spiro B (1996) The geological and metallogenic setting of stratabound carbonate-hosted $\mathrm{Zn}-\mathrm{Pb}$ mineralizations in the West Asturian Leonese Zone, NW Spain. Miner Deposita 31:27-40 
Tischendorf G, Bielicki KH, Franzke HJ (1993) On the genesis of Permian and Post-Permian hydrothermal mineralizations in the Harz Mountains according to new $\mathrm{Pb}$-isotope measurements. Monogr Ser Miner Deposita 30:65-76

Trincherini PR, Barbero P, Quarati P, Domergue C, Long L (2001) Where do the lead ingots of the Saintes-Mariesde-la-Mer wreck come from? Archaeology compared with physics. Archaeometry 43:393-406

Vagnetti L, Stos-Gale ZA, Gale NH (1986) Testimonianze di metallurgia minoica dalla zona di Nerokourou (Kydonias). Studi Micenei ed Egeo-Anatolici 27:155171

Valera PG, Valera RG, Rivoldini A (2005) Sardinian ore deposits and metals in the Bronze Age. In: Lo Schiavo F, Giumlia-Mair A, Sanna U, Valera RG (eds) Archaeometallurgy in Sardinia: from the origins to the beginning of the Early Iron Age. Monographies Instrumentum 30, Montagnac, pp 43-87

Vavelidis M, Bassiakos I, Begemann F, Patriarcheas K, Pernicka E, Schmitt-Strecker S, Wagner GA (1985) Geologie und Erzvorkommen. In: Wagner GA, Weisgerber G (eds) Silber, Blei und Gold auf Sifnos: prähistorische und antike Metallproduktion. Bochum, Vereinigung der Freunde von Kunst und Kultur im Bergbau e.V. Der Anschnitt Beiheft 3. Veröffentlichungen aus dem Deutschen BergbauMuseum Bochum 31, pp 59-80

Velasco F, Pesquera A, Herrero JM (1996) Lead isotope study of $\mathrm{Zn}-\mathrm{Pb}$ ore deposits associated with the BasqueCantabrian basin and Paleozoic basement, northern Spain. Miner Deposita 31:84-92

Villaseca C, López García JA, Barbero L (2005) Estudio de la composición isotópica $(\mathrm{Pb}-\mathrm{S}-\mathrm{O})$ de las mineralizaciones $\mathrm{Pb}-\mathrm{Zn}$ de Mazarambroz (Banda Milonítica de Toledo). Geogaceta 38:271-274

Vogt ML (2002) Etude minéralogique et géochimique du filon à $\mathrm{Pb}-\mathrm{Zn}-\mathrm{Cu}$ du Dorneloch (Steinbach, France). Dissertation, Université de Lausanne

von Quadt A (1985) Geochronologische, geochemische und isotopengeochemische Untersuchungen an Gesteinen der Habach-Formation, der Scheelitlagerstätte und des angrenzenden Altkristallins im Felbertal (Land Salzburg). Dissertation, ETH Zürich

Wagner GA, Pernicka E, Seeliger TC, Lorenz IB, Begemann F, Schmitt-Strecker S, Eibner C, Öztunali Ö (1986) Geochemische und isotopische Charakteristika früher Rohstoffquellen für Kupfer, Blei, Silber und Gold in der Türkey. Jahrb Römisch-Germanisch Zentralmuseum Mainz 33(2): 723-752

Wagner GA, Wagner I, Öztunali Ö, Schmitt-Strecker S, Begemann F (2003) Archäometallurgischer Bericht über Feldforschung in Anatolien und bleiisotopische Studien an Erzen und Schlacken. In: Stöllner T, Körlin G, Steffens G,
Cierny J (eds) Man and mining-Mensch und Bergbau: studies in honour of Gert Weisgerber on occasion of his 65th birthday, Bochum, Der Anschnitt, Beiheft 16, Veröffentlichungen aus dem Deutschen Bergbau-Museum Bochum 114, pp 475-494

Wagner T (1999) Spätvaristische hydrothermale Mineralisationen im Rheinischen Schiefergebirge. Dissertation, University of Freiberg, Germany

Wagner T, Schneider J (1999) Ore remobilization related to sulphide-sulphosalt reactions in hydrothermal vein systems of the Dörnberg-Aurora (Ramsbeck) deposit, NW Germany: evidence from small-scale Pb-isotopic studies. In: Stanley CJ (ed) Mineral Deposits: Processes to Processing. Proceedings 5th biennial and 10th quadrennial IAGOD symposium, Balkema, Rotterdam, pp 995-998

Wagner T, Schneider J (2002) Lead isotope systematics of vein-type antimony mineralization, Rheinisches Schiefergebirge, Germany: a case history of complex reaction and remobilization processes. Miner Deposita 37:185-197

Webb JM, Frankel D, Stos ZA, Gale N (2006) Early Bronze age metal trade in the Eastern Mediterranean: new compositional and lead isotope evidence from Cyprus. Oxford J Archaeol 25(3):261-288

Wedepohl KH, Delevaux MH, Bruce RD (1978) The potential source of lead in the Permian Kupferschiefer Bed of Europe and some selected paleozoic mineral deposits in the Federal Republic of Germany. Contrib Miner Petrol 65:273-281

Weeks L, Keall E, Pashley V, Evans J, Stock S (2008) Lead isotope analyses of Bronze Age copper-base artefact from Al-Midamman, Yemen: towards the identification of an indigenous metal production and exchange system in the southern Red Sea region. Archaeometry 51:576-597

Willet F, Sayre EV (2006) Lead isotope in West African copper alloys. J African Archaeol 4(1):55-90

Wooden JL, Czamanske GK, Bouse RM, Likhachev AP, Kunilov VE, Lyul'ko V (1992) Pb isotope data indicate complex, mantle origin for the Noril'sk-Talnakh ores, Siberia. Econ Geol 87:1153-1165

Yener KA, Sayre EV, Joel EC, Özbal H, Barnes IL, Brill RH (1991) Stable lead isotope studies of Central Taurus ore sources and related artifacts from Eastern Mediterranean Chalcolithic and Bronze age sites. J Archaeol Sci 18:541577

Zingg M (1989) Die Siviez-Mischabel Decke: Entstehung und Entwicklung eines Altkristallins und seiner Vererzungen (Wallis, Schweiz). Dissertation, ETH Zurich

Zwicker U, Gale NH, Stos-Gale ZA (1991) Metallographische, analytische und technologische Untersu- 
chungen sowie Messungen der Bleiisotope an OttoAdelheid-Pfennigen und Vergleichsmünzen meist aus dem 9.-11. Jahrhundert. In: Hatz G, Hatz V, Zwicker U, Gale NH, Stos-Gale Z (eds) Otto-Adelheid-Pfennige. Commentationes de Nummis Saeculorum IX-XI, Stockholm, pp 59-146
Zwicker U, Stos-Gale ZA, Gale NH (1989) A study of the metal provenance of some silver quinars from southern Germany using metallurgical and lead isotope analyses. In: Carradice IA (ed) Proceedings of the 10 International Numismatic Congress. International Association of Professional Numismatists, Publication 11. London, pp 117-124 